\title{
POLYMIALGIA RHEUMATICA, GIANT CELL ARTERITIS OR BOTH?
}

\author{
Adina Cociorvei ${ }^{1}$, Mădălina Ababei \\ ${ }^{1}$ Carol Davila University of Medicine and Pharmacy, Bucharest, Romania \\ Elias Emergency Hospital \\ ${ }^{2}$ Elias Emergency Hospital \\ Correspondent author: adinacociorvei@yahoo.com
}

\section{Rezumat}

Arterita cu celule gigante (arterita temporală) este cea mai des intâlnită vasculită, cel mai mare risc în a dezvolta acest tip de vasculită fiind îmbătrânirea. Vasculita cu celule gigante apare la adulții de peste 50 de ani, cea mai mare incidență fiind înregistrată între 70 și 79 de ani, riscul de apariție a bolii fiind de aproximativ 2 ori mai mare la femei.

Polimialgia reumatică reprezintă o boala osteoarticulară autolimitată, caracterizată prin dureri și redoare articulară, mai ales la nivelul centurilor scapulară și pelviană. La fel ca și arterita cu celule gigante, polimialgia reumatică este o boală care apare la adulții peste 50 ani, incidența crescând cu vârsta, astfel încât vârful de incidență este între 70 și 80 ani, boala fiind de 2-3 ori mai frecventă la femei.

Aceste două condiții prezintă numeroase semne clinice și paraclinice comune și, în multe cazuri, coexistă (50\% dintre pacienții cu arterită cu celule gigante asociază și polimialgie reumatică și aproximativ 30\% dintre pacienții cu polimialgie reumatică au și arterită cu celule gigante). Polimialgia reumatică poate precede, se poate asocia, sau poate aparea după arterita cu celule gigante.

În cazul polimialgiei reumatice, diagnosticul se susține în primul rând prin argumente clinice. În ceea ce privește arterita cu celule gigante, este recomandat un algoritm de diagnostic, descris în figura 1. Nu este necesară întotdeauna biopsia de arteră temporală pentru a susține diagnosticul, dacă există o suspiciune înaltă bazată pe date clinice și paraclinice.

Vom prezenta cazul unui pacient de 81 de ani care ilustrează asocierea diferitelor semne, simptome, modificări biologice, care apar în aceste două boli.

Cuvinte cheie: polimialgie reumatică, arterită cu celule gigante, asociere, vasculită, îmbătrânire. 


\title{
INTE
}

\begin{abstract}
Giant cell arteritis (GCA), or temporal arteritis, is the most common systemic vasculitis, and the greatest risk factor for developing GCA is aging. The disease almost never occurs before age 50, and its incidence rises steadily thereafter, peaking between ages 70 to 79, the risk of development being two times higher in women.

Polymialgia rheumatica (PMR) is an inflammatory rheumatic condition characterized clinically by aching and morning stiffness at the shoulders, hip girdle, and neck. PMR is almost exclusively a disease of adults over the age of 50, with a prevalence that increases progressively with advancing age. The peak incidence of PMR occurs between ages 70 and 80 , the same as in the case of GCA. PMR is 2-3 times more common in women than in men.

$P M R$ is two to three times more common than GCA and occurs in about $50 \%$ of patients with GCA. The percentage of patients with PMR who experience GCA at some point varies widely in reported series ranging from 5 to 30 percent. PMR can precede, accompany or follow GCA. The diagnostic in the case of PMR is made first of all on clinical features, in the patients in whom another disease to explain the findings is not present. For GCA we must follow the diagnostic algorithm presented below (figure 1) and keep in mind that a negative result for temporal artery biopsy does not exclude the diagnostic if clinical suspicion of GCA is high.

We present the case of a 81 year-old male with signs and symptoms from both conditions, PMR and GCA.
\end{abstract}

Keywords: polymialgia rheumatica, giant cell arteritis, overlap, vasculitis, aging 


\section{Introduction}

Giant cell arteritis (GCA) and polymialgia rheumatica (PMR) are two related conditions. GCA (or temporal arteritis) is the most common systemic vasculitis. In the United States population, the lifetime risk of developing GCA has been estimated at approximately $1 \%$ in women and $0,5 \%$ in men $^{(2)}$.The greatest risk factor for developing GCA is aging. The disease almost never occurs before age 50 , and its incidence rises steadily thereafter, peaking between ages 70 to $79^{(5)}$. In addition to age, ethnicity is a major risk factor for GCA. The highest incidence figures are found in Scandinavian countries and among Americans of Scandinavian descent. PMR is an inflammatory rheumatic condition characterized clinically by aching and morning stiffness about the shoulders, hip girdle, and neck. It can be associated with GCA, and the two disorders may represent different manifestations of a shared disease process. PMR is almost exclusively a disease of adults over the age of 50 , with a prevalence that increases progressively with advancing age.

The peak incidence of PMR occurs between ages 70 and 80 , the same as in the case of $\mathrm{GCA}^{(1)}$. PMR is relatively common. The life time risk of PMR is second only to rheumatoid arthritis as a systemic rheumatic disease in adults $^{(2)}$. Women are affected two to three times more often than men, with cases of familial aggregation ${ }^{(3)}$. The annual incidence varies geographically and is highest in Scandinavian countries and in people of northern European descent.

PMR is two to three times more common than GCA and occurs in about $50 \%$ of patients with GCA. The percentage of patients with PMR who experience GCA at some point varies widely in reported series ranging from 5 to 30 percent. PMR can precede, accompany or follow $\mathrm{GCA}^{(5)}$. The precise nature of the relationship between GCA and PMR is not completely understood. In some patients, symptoms and signs of the two conditions occur simultaneously, while in others they appear separately over time.

The diagnostic in the case of PMR is made first of all on clinical features, in the patients in whom another disease to explain the findings is not present.

For GCA we must follow the diagnostic algorithm presented below ${ }^{(6)}$, and keep in mind that a negative result for temporal artery biopsy does not exclude the diagnostic if clinical suspicion of GCA is high.

\section{Case presentation}

We report the case of a 81-years-old male patient who was admitted to the Internal Medicine Department with the following complaints: shoulder and pelvic girdles pain, with significant movement restriction and morning stiffness (more than 60 minutes, every morning), inconstant headache, and constitutional manifestations such as: fever (up to $38,2^{\circ} \mathrm{C}$ ), depression, malaise, weight loss (with loss of appetite) and general weakness. The patient fell ill unexpectedly 4 weeks ago, the onset of the symptoms being quite sudden. He was treated with diclofenac gel without any significant effect. The subject had no relevant medical history or any exposure to toxic substances

On admission, the clinical examination revealed: fever $\left(38^{\circ} \mathrm{C}\right)$, tenderness on palpation of the shoulder and hip girdles with restricted active motion and swelling of the metacarpophalangeal joints. The patient could hardly walk and lift his hands. There was no abnormalities in the clinical examination of the lungs and heart, the heart rate was 98 bpm, with blood pressure of $130 / 60 \mathrm{mmHg}$. 


\section{INTERNAI}

Clinical cases

There were no pathological features in the abdominal examination or in passing urine or stool. The neurological examination was normal. The patient did not have diminished pulses or discrepant blood pressure in the arms, but the temporal artery was thickened.

Blood tests showed: mild leukocytosis with neutrophilia (12450/uL with $\mathrm{Ne}=9790 / \mathrm{uL}$ ), mild normochromic normocytic anemia ( $\mathrm{Hb}$ $9.3 \mathrm{~g} / \mathrm{dL}$ ) (with low iron level - $14 \mathrm{ug} / \mathrm{dL}$ ), mild thrombocytosis $(507000 / \mathrm{uL})$, increased inflammatory markers with ESR $79 \mathrm{~mm} / \mathrm{h}$ (normal range $<20 \mathrm{~mm} / \mathrm{h}$ ) and PCR, but seric procalcitonine slightly elevated $(1.7 \mathrm{ng} / \mathrm{mL})$ and mild hyponatremia ( $124 \mathrm{mmol} / \mathrm{L}$ ).

The creatine-phosphokinase was in normal range - $63 \mathrm{U} / \mathrm{I}$. The rheumatoid factor, the anticyclic citrullinated peptide antibodies (CCP), anti-nuclear and anti-neutrophil cytoplasmic antibody (ANCA) tests were negative. A urine culture and 4 sets of hemocultures were negative. The tumor markers (PSA, CA19-9 and CEA) were negative.

The radiological examination of the shoulders and hip did not detect any pathology. The echocardiography revealed normal cardiac morphology and function with normal function (LVEF 50\%) and aortic valve calcifications. There were no signs of endocarditis. The esophagogastroduo-denoscopy revealed atrophic pangastritis, with no abnormalities pointing an oncological disease. The CT scan (head, thorax, abdomen and pelvis) revealed cerebral atrophy and fibrous lesions in superior pulmonary lobes compatible with tuberculosis sequelae but with no signs of reactivation (also, a sputum specimen was negative for acid-alcohol-resistant bacilli). There were no signs of an oncological disease on the CT scan. The fundoscopy revealed anterior ischemic optic neuropathy.

\section{Discussions}

When the diagnosis of PMR is considered, two main issues arise:

- How is the diagnosis established and distinguished from other disorders that can produce similar symptoms?

- Does the patient also have GCA?

In this case we are talking about a 81 years old male that appears to be systemically ill at physical examination, with malaise, fever, fatigue, weight loss, symptoms associated with swelling of the joints in the hands, and pain in the shoulder and hip girdle, symptoms that begun with 3-4 weeks before presentation, and with only a few ophthalmological signs (headache and anterior ischemic optic neuropathy). The patient doesn't have diminished pulses and discrepant blood pressure in the arms, but the temporal artery was thickened.

Blood test showed elevated ESR and Creactive protein, and a mild normochromic normocytic anemia. 
First of all, we ruled out infections (bacterial endocarditis, tuberculosis) because the culture and procalcitonine were negative, and malignancies (including hematological malignancies as lymphoma or multiple myeloma) because the whole body computed tomography showed no tumor at any level of examination (head, thoracic, abdominal and pelvic). Other differential diagnosis problems can be:

- rheumatoid arthritis was excluded taking into consideration patient's age, the polyarthritis with only a few joints swollen and the fact that swollen subsides completely in response to low dose of prednisone. Rheumatoid factor and antibodies anti-CCP were both negative.

- RS3PE syndrome (Remitting Seronegative Symmetrical Synovitis with Pitting Edema) was excluded for clinical reasons, in this case because the patient also have stiffness and pain in the shoulder and hip girdle, not only swelling of the little joints in the hands, and because all symptoms respond at low dose of prednisone.

- multifocal local musculoskeletal disease, like subacromial/subdeltoid bursitis or rotator cuff tendinitis, a pathology that is common in older adults, but in this case, the morning stiffness is brief, constitutional symptoms are absent and the acute phase reactants are not elevated.

- bone disease as multiple myeloma, multiple skeletal metastases, hypercalcemia, osteomalacia with multiple fractures, were ruled out on clinical, imaging and biological grounds.

- drug induced myalgia or myositis , in the case of statins, for example, but serum creatine-kinase levels were normal and there is no indications of statin treatment before the symptoms appears.

- inflammatory myopathy, like in dermatomyositis or polymyositis, but this situation was ruled out on clinical and biological (normal levels of muscle enzymes) arguments.

- other vasculitic disorders, like granulomatosis with polyangiitis (ANCA-associated vasculitis), but the tests for ANCA antibodies were negative.

- Parkinson disease, but neurological exam was normal.

So, the conclusion was that we have a patient with PMR, and the diagnostic was made with the following features:

1. more than 50 years old at onset of symptoms;

2. bilateral involvement with pain and stiffness persisting for more than 2 weeks in shoulders and hip girdle, neck, and in the little joints in the hands;

3. systemic symptoms like small fever (until 38 degrees Celsius), malaise, gain loss;

4. inflammatory biological markers (elevated ESR, above $40 \mathrm{~mm} / \mathrm{h}$, elevated CRP) and mild normocytic anemia;

We started the glucocorticoid therapy with 15 mg prednisone/day (the dosage normally accepted for PMR), and the generally condition of the patient improved significantly, but with still elevated values for ESR and CRP, although lower than the initial values.

So, we think at PMR and GCA, taking into consideration that the patient has also headache and anterior ischemic optic 


\section{INTERNAL}

\section{Clinical cases}

neuropathy (established at fundoscopy). Unfortunately the patient refused the temporal artery biopsy.

In this case we perform color Doppler ultrasonography (CDUS) for temporal arteries. The CDUS didn't showed the highly specific 'halo sign" of the temporal arteries, nor the "compression sign". So, we considered that the patient has a nondiagnostic initial evaluation for GCA. There are some explanations for a patient with a negative workup:

1. The CDUS failed to detect the area with vascular pathology possibly due to "skip areas" and the segmental nature of arteritis

2. The patient has GCA but a disease phenotype not associated with cranial arteritis, and we must think at large vessel GCA.

We follow the algorithm for diagnosis of GCAsee below (https//www.uptodate.com) ${ }^{(6)}$ and make an evaluation for large vessel GCA with computed tomography with angiography, that showed only atherosclerotic plaques.

We still consider that the patient has PMR with GCA on clinical criteria and treat accordingly with $40 \mathrm{mg}$ prednisone/day. After two weeks of treatment the patient clinical condition improved significantly and the inflammation biological markers became negative (see table 1). Follow up at one month showed significantly clinical and biological improvement, and we started to reduce the dosage by $5 \mathrm{mg}$ every two weeks

\section{Conclusions}

1. We must think at polymyalgia rheumatica as a possible diagnostic in the case of a patient over 50 years old, with pain in the shoulders and hip girdles, systemic symptoms and biological inflammatory markers, after we ruled out infections and malignancies.

2. Taking into consideration that approximately $5-30 \%$ of the patients with PMR have also $\mathrm{GCA}^{(1,7,8)}$, we must consider GCA in a patient who needs a greater dosage of prednisone (more than 15 $\mathrm{mg} /$ day) and has neurological symptoms as headache and ophtalmopathy.

3. Like in algorithm for the diagnosis of $\mathrm{GCA}^{(6)}$, we can sustain the diagnosis without the temporal artery biopsy, only with clinical arguments, biological inflammatory markers, and, maybe, CDUS for temporal artery. It is also important to evaluate the response at corticotherapy.

4. CDUS can be false negative in GCA, due to "skip areas" and the segmental nature of arteritis.

5. Follow up is very important especially in the case of a patient with presumed GCA but without temporal artery biopsy, because a prompt response to corticotherapy (recommended dosage being prednisone $1 \mathrm{mg} / \mathrm{kg}$ ) can be a argument for GCA. 
Is there a clinical suspicion for GCA after evaluating for other causes of symptoms? Suggestive signs and symptoms include the presence of one or more of the following in a patient aged $\geq 50: *$

- New headache

- Abrupt onset of visual disturbances, especially transient monocular visual loss

- Jaw claudication

- Unexplained fever, anemia, or other constitutional symptoms and signs

- High ESR and/or CRP**

\section{YES}

- Evaluate the temporal artery promptly with biopsy or CDUS***

- Urgent ophthalmologic evaluation in patients with transient monocular visual loss

Is the temporal artery biopsy (or CDUS) positive for GCA?
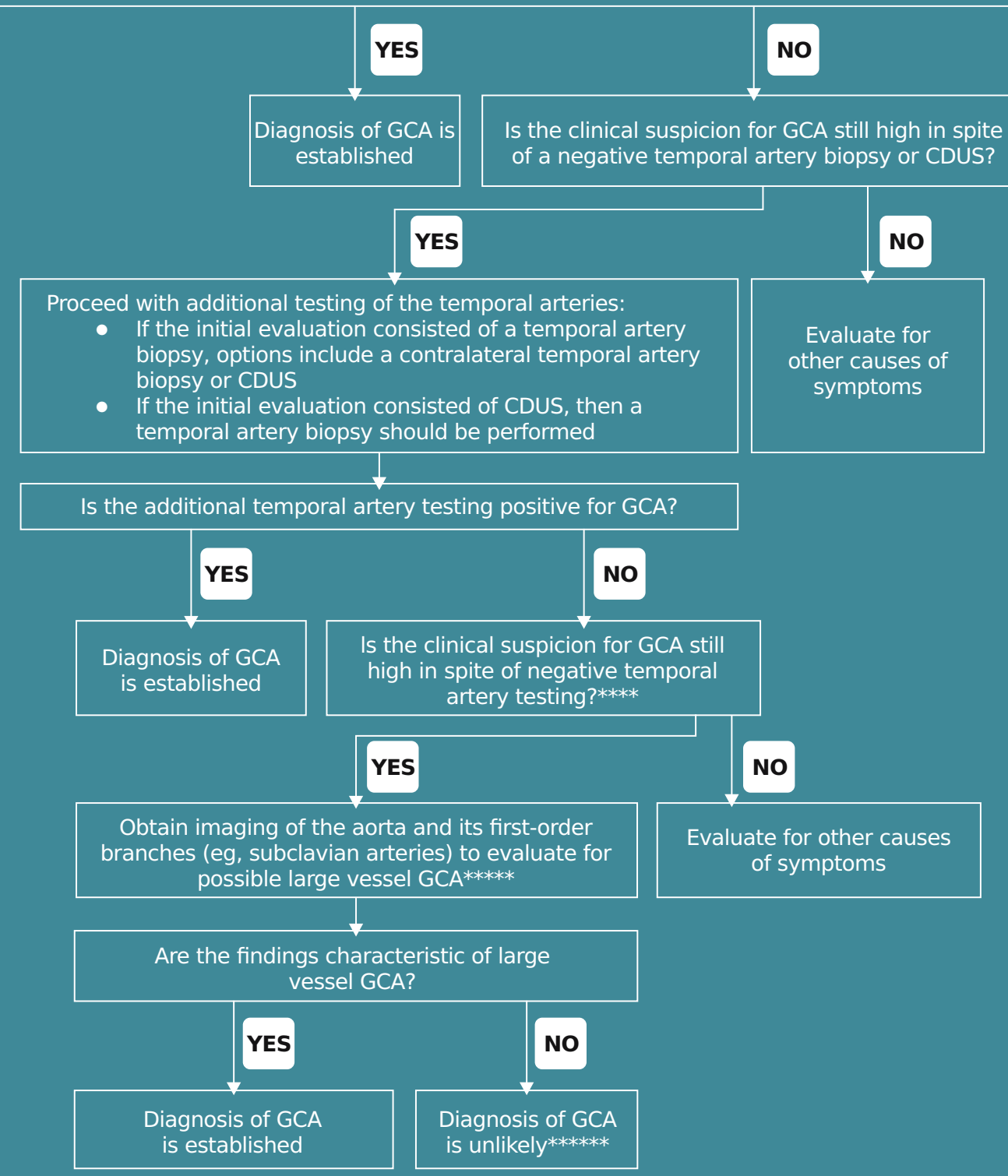


\section{INTER}

\begin{tabular}{|c|c|c|c|c|}
\hline & At admission & At discharge & $\begin{array}{c}\text { 2weeks after } \\
\text { discharge }\end{array}$ & $\begin{array}{c}\text { 1 month after } \\
\text { discharge }\end{array}$ \\
\hline $\begin{array}{c}\text { Leucocytes (/uL) } \\
\text { Hemoglobin } \\
\text { (g/dL) }\end{array}$ & 12450 & 12380 & 12570 & 15110 \\
\hline Platelets (/ul) & 507000 & 9.8 & 13.6 & 14.2 \\
\hline ESR (mm/h) & 79 & 688000 & 312000 & 346000 \\
\hline PCR hs (mg/L) & 164 & 79 & 11 & 14 \\
\hline Sodium (mmol/L) & 124 & 78 & 3.11 & 1.84 \\
\hline \multicolumn{7}{|l|}{} & 132 & 134 & 136 \\
\hline
\end{tabular}

Table 1. Laboratory data

\section{References}

1. Salvarani C, Gabriel SE, O'Fallon WM, Hunder GG. Epidemiology of polymyalgia rheumatica in Olmsted County, Minnesota, 1970-1971, Arthritis Rheum 1995; 38:369

2. Crowson CS, Matteson EL, Myasoedova E, et al. The lifetime risk of adult-onset rheumatoid arthritis and other inflammatory autoimmune rheumatic diseases. Arthris Rheum 2011;63:633

3. Liozon E, Ouattara B, Rhaiem $K$, et al. Familial aggregation in giant cell arteritis and polymyalgia rheumatic: a comprehensive literature review including 4 new families. Clin Exp Rheumatol 2009;27:S89

4. Gonzales-Gay MA, Vazquez-Rodriguez TR, LopezDiaz MJ, et al. Epidemiology of giant cell arteritis and polymyalgia rheumatic. Arthris Rheum 2009;61:1454

5. Salvarani C, Gabriel SE, O'Fallon WM, Hunder GG. The incidence og giant cell arteritis in Olmsted County, Minnesota:apparent fluctuation in a cyclic pattern. Ann Intern Med 1995; 123:192

6. https://www. uptodate.com

7. Gonzales-Gay MA, Garcia-PorruaC, VazquezCaruncho $M$, et al. The spectrum of polymyalgia rheumatic in northwestern Spain: incidence and analysis of variables associated with relapse in a 10 year study. J Rheumatol 1999;26:1326

8. Gran JT, Myklebust B, Wilsgaard T, Jacobsen BK. Survival in polymyalgia rheumatica and temporal arteritis: a study of 398 cases and matched population controls. Rheumatology (Oxford) 2001; 40:1238 